\title{
MIR181B2 wt Allele
}

National Cancer Institute

\section{Source}

National Cancer Institute. MIR181B2 wt Allele. NCI Thesaurus. Code C82123.

Human MIR181B2 wild-type allele is located in the vicinity of 9q33.3 and is 88 bases in length. This allele, which encodes MIR181B2 pre-miRNA, plays a role in the regulation of gene expression. Alteration in the expression of this gene is associated with development of glioma, multiple myeloma and chronic lymphocytic leukemia. 